\title{
Maternal prenatal history and neonatal risk complications for low-weight for gestational age term newborns
}

\author{
Karina L. Arce-López ${ }^{1}$, Juan Vicencio-Rivas², José Iglesias-Leboreiro ${ }^{1,2}$, Isabel Bernárdez-Zapata ${ }^{1,2}$, \\ Mario E. Rendón-Macías²* and Ariela Braverman-Bronstein ${ }^{2}$ \\ ${ }^{1}$ Facultad Mexicana de Medicina, Universidad La Salle; ${ }^{2}$ Hospital Español de México. Mexico City, Mexico
}

\begin{abstract}
Background: Low-birth-weight (LBW $<2.5 \mathrm{~kg}$ or $<10$ percentile) could be caused by constitutional matters (small for gestational age) or by intrauterine growth restriction (IUGR), both with different neonatal complications. Without an adequate prenatal evaluation, it is hard to establish those conditions. Knowing the maternal history for gestational diseases (MHGD), such as hypertension, hypothyroidism (HT) or diabetes, and among others, could help clarify that difference. This work aimed to determine if having MHGD is associated with neonatal complications in newborns with LWB. Methods: Retrospective cohort study, which included 349 with LWB at term (e 37 WG) grouped into those with or without MHGD at a hospital nursery. The frequency of respiratory distress (RD), hypoglycemia (HG), and hyperbilirubinemia $(\mathrm{HBr})$ was determined. Results: Nearly $16.6 \%$ (58/349) had MHGD (58.6\% for HBP and 41.3\% for HT alone or combined). The neonate with MHGD was more borderline term (37 WGA, 55.2\% vs. 35.1\%, $p=0.037$ ), and had lower weight (difference near $100 \mathrm{~g} ; p=0.028$ ), had more cases with $\mathrm{HG}\left(13.6 \%\right.$; $\mathrm{Cl}_{95 \%}-4.08-31.2 \%$ ) but developed less $\mathrm{RD}$ (difference of $-4.7 \%$; $\mathrm{Cl}_{95 \%}$ : $-20.6-11.05 \%$ ). $\mathrm{HG}$ in 39 WGA was only seen among neonates without MHGD (difference 12.7\%; $\mathrm{Cl}_{95 \%}=3.9-31.5 \%$ ) just as for the $\mathrm{HBr}$ cases (three). Conclusions: Inquiring about the MHGD on low-birth-weight term babies could be useful in the inference of IUGR, although we need other tools so that altogether can help to predict complications and to plan preventive actions.
\end{abstract}

Key words: Low-birth-weight. Intrauterine growth restriction. Maternal history of a gestational disease.

\section{Antecedentes maternos prenatales y riesgo de complicaciones neonatales en productos de término de bajo peso para edad gestacional}

\section{Resumen}

Introducción: El bajo peso neonatal $(<2.5 \mathrm{~kg} 0<$ percentil 10) se atribuye a causas constitucionales (pequeño para la edad gestacional [PEG]) o a la restricción en el crecimiento intrauterino (RCIU), con riesgos posnatales diferentes. En ausencia de una valoración fetal-placentaria prenatal adecuada, resulta difícil establecerlo. El conocer los antecedentes maternos de enfermedades gestacionales (AMEG): hipertensión arterial (HTA), hipotiroidismo, Diabetes Mellitus (DM) gestacional

Correspondence:

*Mario Enrique Rendón-Macías

E-mail: drmariorendon@gmail.com
Available online: 23-11-2018 Bol Med Hosp Infant Mex. 2018;75:205-211

www.bmhim.com

2444-3409/@ 2018. Hospital Infantil de México Federico Gómez, published by Permanyer México SA de CV, all rights reserved. 
y otra; pudiera orientar a la diferenciación y el manejo. El objetivo de este trabajo fue determinar si la presencia de AMEG se asocia a complicaciones neonatales en productos de bajo peso neonatal. Métodos: Se realizó un estudio de cohorte retrospectivo en un grupo de 349 recién nacidos vivos de término ( $\geq 37$ semanas de edad gestacional [SEG]), PEG, en cunero fisiológico y agrupados según los AMEG. Se determinó la frecuencia de dificultad respiratoria (DR), hipoglucemia (HG) e hiperbilirrubinemia (HBr). Resultados: El 16.6\% (58/349) presentó AMEG (58.6\% HTA y 41.3\% hipotiroidismo, solos o combinados). Los neonates con AMEG fueron más limítrofes (37 SEG, 55.2\% vs. 35.1\%; $p=0.037$ ). Los de 37 SEG con menor peso (diferencia de $\approx 100 \mathrm{~g} ; p=0.028$ ), más riesgo de HG (13.6\%; intervalo de confianza al 95\% [IC 95\%]: -4.08-31.2) pero menos DR (diferencia de -4.7\%; IC 95\%: -20.6-11.05). La HG en los de 39 SEG solo se presentó en neonatos sin AMEG (diferencia 12.7\%; IC 95\%: 3.9 a 31.5) igual que la $\mathrm{HBr}$ (tres casos). Conclusiones: Indagar sobre los AMEG en un producto PEG parece ser útil en la inferencia de RCIU. Sin embargo, es insuficiente, por lo que en conjunto con otras herramientas nos ayuda a estimar posibles complicaciones y acciones preventivas.

Palabras clave: Bajo-peso al nacer. Restricción del crecimiento intrauterino. Pequeño para edad gestacional. Antecedentes maternos.

\section{Introduction}

The World Health Organization has emphasized the importance of low-birth-weight neonates (LBWN) $(<2.5 \mathrm{~kg})$, due to the 20 -times higher risk of dying in the neonatal stage compared with neonates of adequate weight. ${ }^{1-3}$ However, due to the influence of gestational age on weight, LBW is currently defined when the weight is below two standard deviations from the mean or below the percentile 10 for gestational age..$^{2,4-6}$ Nevertheless, this risk may diverge as of the cause of the weight deficiency. According to the above, the classification as small for gestational age (SGA) is given generally for constitutional reasons, such as sex or ethnicity ${ }^{7}$, or when the biometrics, evaluated by ultrasound during the fetal stage, was always below this percentile but maintaining a constant growth until birth. Newborns with intrauterine growth restriction (IUGR) are classified when fetal growth was demonstrated below their genetic potential below the $3^{\text {rd }}$ percentile and accompanied by alterations in the placental, uterine or fetal flow by Doppler ultrasound, secondary to a cause placental, maternal, or some fetal malformation. ${ }^{1,4,6}$ In turn, the IUGR can occur symmetrically (the head and abdomen are proportionally diminished by cellular hypoplasia in the organs) or asymmetric (the head is greater than the abdomen by redistribution of cardiac output to vital organs during chronic hypoxia). ${ }^{1}$ The latter explains $80 \%$ of the cases. Similarly, in neonates with IUGR, a higher frequency of postnatal complications had been found, such as hypoglycemia $(\mathrm{HG})$, hyperbilirubinemia $(\mathrm{HBr})$, polycythemia, respiratory distress (RD), and among others. ${ }^{1,3,5}$

In many occasions, it is difficult to establish when the low weight of a newborn was due to IUGR if there was no adequate prenatal fetal-placental ultrasonographic follow-up, except in patients with apparent malformations.

Previous studies have shown that various maternal conditions, such as the mother's age $(<16$ years or $>35$ years), low socioeconomic level, low body mass index before pregnancy, anemia, hypertensive disorders of pregnancy (HDP), diabetes, hypothyroidism $(\mathrm{HT})$, or addictions, such as alcoholism or smoking, have been associated with SGA, and especially with IUGR. ${ }^{1,2,8,9}$

In general, it is not uncommon for neonatologists and pediatricians to face the attention of a newborn SGA without having information on intrauterine growth, and although they may suspect the cause of low weight (IUGR), especially if there is an asymmetric growth, in many occasions such precision is fallible. Given the high frequency of maternal history in neonates with IUGR at higher postnatal risk, these could be used as markers for closer monitoring or preventive actions.

Based on the above, in this study, it was determined whether the existence of gestational maternal history in children with LBW is associated with a higher rate of early postnatal complications. If so, their investigation and confirmation will impact on primary or secondary preventive actions granted by the doctors who treat these neonates.

\section{Methods}

A retrospective cohort study was conducted. We included 349 full-term live births ( $\geq 37$ weeks of gestational age [WG] obtained by date of last menstruation) and with a weight below the $10^{\text {th }}$ percentile according to Juradotables ${ }^{10}$, which are used to classify to newborns in our unit. To estimate the sample size, we assume a minimum of $15 \%$ of mothers with at least one 
prenatal history, with an expected incidence of $\mathrm{HG}$ (most likely complication) in these neonates of at least $30 \%$ and with a difference expected from a risk of 2.3, a power of $80 \%$ and a risk of type I error of $p<0.05$. A minimum of 58 neonates was estimated to be children of mothers with some history and 250 without precedents (www.sample-size.net). Products from multiple pregnancies, critically ill preterm infants (admitted to intensive neonatal therapy), infants with congenital malformations or chromosomopathies and those programmed to a surgical procedure in the immediate postnatal period $(<48 \mathrm{~h})$ were excluded. Of all infants, sex, gestational age, birth path, 5 min Apgar, birth weight and height were recorded.

As part of the close monitoring due to their low weight, these neonates were admitted to the physiological nursery. They were evaluated every hour to determine the presence of any of the following conditions: RD defined as the increase in respiratory rate above 60 breaths per minute and some RD data on the Silverman Anderson scale; ${ }^{11} \mathrm{HG}$ determined by capillary glucose measurement values $<45 \mathrm{mg} / \mathrm{dl}$, with or without clinical data (diaphoresis, tremor, or seizure) ${ }^{12}$. In all patients, the measurement was performed at birth, at 30 and $60 \mathrm{~min}$ after, or at any time if there were symptoms; $\mathrm{HBr}$ was only determined in those patients with jaundice (Kramer II) and confirmed by the elevation of indirect serum bilirubin above the critical values according to the standard. ${ }^{13,14}$ This surveillance was maintained until discharge or if they merited hospitalization in the Neonatal Intensive Care Unit (NICU). Subsequent complications were not evaluated.

Moreover, information on age, drug addiction (smoking and alcoholism), and the presence of any of the following prenatal records were collected from the mothers' files: HDPs, gestational diabetes (GD), HT, or another, establishing the diagnosis by meeting the criteria set in the Clinical Practice Guidelines.

\section{Statistical analysis}

The patients were grouped based on the presence of mothers with a history of prenatal diseases.

All the qualitative variables were summarized in simple and relative frequencies in percentage by the group and contrasted with two-tailed Fisher's exact test or Chi-square test in their options according to the type of variable (maximum likelihood ratio or linear by linear). For the quantitative variables, they were summarized in medians with their range (minimum and maximum) or with means and standard deviations according to their distribution of data. The test was performed with the Mann-Whitney U-test or the unpaired Student's $t$-test, following the above criteria.

Complications were calculated as cumulative incidence rates at discharge or admission to NICU in percentages for each complication (RD, $\mathrm{HG}$, or $\mathrm{HBr}$ ) and established by gestational age $(37,38,39$, and 40-41 WG).

Absolute risks or risk differences were calculated with their $95 \%$ confidence intervals to determine the effect of mothers' prenatal history on the greater or lesser presentation of complications. A statistically significant difference was considered in the absence of the value of " 0 " within the interval.

The analyzes were performed with the statistical package SPSS version 20. The level of statistical significance was established with $p<0.05$.

\section{Results}

The inclusion criteria were met by 349 neonates with LBW, of which $16.6 \%$ (58/349) were children of mothers with some prenatal disease.

Table 1 shows the comparison of the state of the mothers. Although no statistical significance was observed, mothers with some history were 1 year older $(p=0.06)$ and $18 \%$ more were over 34 years old $(p=0.012)$. Concerning the proportion of mothers who consumed alcohol, tobacco, or both, no statistically significant differences were found.

In the group of mothers with prenatal diseases, hypertensive disease alone or combined occurred in $>50 \%$. The second most common disease was $\mathrm{HT}$ ( $\approx 40 \%$ ). GD was present in $8.5 \%$ of this group.

Regarding the characteristics of the newborns, in both groups, the female sex predominated (64.2\%). Although all were term infants, the children of mothers with the referred history were mostly of $37 \mathrm{GW}(55.2 \%)$, as opposed to $38 \mathrm{GW}$ for the children of mothers without prenatal disease $(p=0.037)$. Concerning the delivery method, there were no differences between the groups, and resolution by cesarean section prevailed in both. None of the patients got an Apgar $<7$, and $91.1 \%$ got an Apgar score of 9 at $5 \mathrm{~min}$.

On the topic of somatometry at birth, no statistically significant differences in the evaluation of weight between both groups were observed, except for neonates of $37 \mathrm{GW}$. In $37 \mathrm{GW}$ neonates, the weight of the children of mothers with a prenatal disease was lower versus healthy mothers (difference of $\approx 100 \mathrm{~g}$, $p=0.028$ ). The size was also very similar between the 
Table 1. Characteristics of mothers according to their prenatal disease history.

\begin{tabular}{|c|c|c|c|c|}
\hline & $\begin{array}{c}\text { History } \\
\mathrm{n}=58(\%)\end{array}$ & $\begin{array}{c}\text { No history } \\
n=291\end{array}$ & $\begin{array}{l}\text { Total } \\
\mathrm{n}=349\end{array}$ & p value \\
\hline $\begin{array}{l}\text { Age (years) } \\
\text { Medium (minimum-maximum) } \\
\text { Mothers }>34 \text { years }\end{array}$ & $\begin{array}{c}35(16-44) \\
58.6(34)\end{array}$ & $\begin{array}{l}34(18-54) \\
40.5(118)\end{array}$ & $\begin{array}{l}34(16-54) \\
43.6(152)\end{array}$ & $\begin{array}{l}0.06^{*} \\
0.012^{\dagger}\end{array}$ \\
\hline $\begin{array}{l}\text { Addictions } \\
\text { Smoking } \\
\text { Alcoholism } \\
\text { Smoking and alcoholism }\end{array}$ & $\begin{array}{l}10.3(6) \\
0 \\
1.7(1)\end{array}$ & $\begin{array}{l}9.7(27) \\
0.3(1) \\
5.8(17)\end{array}$ & $\begin{array}{c}9.5(33) \\
0.3(1) \\
5.2(18)\end{array}$ & $0.24^{\ddagger}$ \\
\hline $\begin{array}{l}\text { Proven disease } \\
\text { Hypertensive disease } \\
\text { HT } \\
\text { Gestational diabetes } \\
\text { HT and diabetes } \\
\text { Hypertension and HT } \\
\text { Hypertension and diabetes } \\
\text { Sickle cell anemia } \\
\text { HBP + DG + HT }\end{array}$ & $\begin{array}{c}51.7(30) \\
32.8(19) \\
3.4(2) \\
3.4(2) \\
3.4(2) \\
1.7(1) \\
1.7(1) \\
1.7(1)\end{array}$ & $\begin{array}{l}- \\
- \\
- \\
- \\
- \\
- \\
- \\
-\end{array}$ & & \\
\hline
\end{tabular}

HBP, systemic high blood pressure; GD: gestational diabetes.

*Mann-Whitney U-test.

${ }^{t} \chi^{2}$ test by likelihood ratio.

${ }^{\ddagger} \chi^{2}$ test linear by linear.

groups, except for the $39 \mathrm{GW}$ neonates, whose size was lower in children of mothers with prenatal disease (difference $\approx 1 \mathrm{~cm}, p=0.039$ ), (Table 2).

\section{Postnatal complications}

For RD, a lower incidence was found in neonates born to mothers with diseases ( 37 and $38 \mathrm{GW}$ ). In particular, there were no cases in $38 \mathrm{GW}$ neonates born to mothers with any illness $(<10 \%$ cases, $95 \% \mathrm{Cl}$ : $5-16)$. For infants of $39 \mathrm{GW}$ or more, the frequency was similar between groups, with a slightly higher percentage if there was a maternal background (Table 3).

Regarding the presentation of $\mathrm{HG}$, all were detected by capillary measurement within the first $6 \mathrm{~h}$ of life and without difference between groups (data not shown) and no patient had associated clinical data. In patients with a history in their mothers, it only occurred in those of 37 and 38 GW and a more significant proportion to the children of healthy mothers, although the differences did not reach statistical significance. As of $39 \mathrm{GW}$, cases were only observed in the group of healthy mothers $(p<0.05)$.

The presence of $\mathrm{HBr}$ was found only in three patients from the group of healthy mothers. It was presented in neonates of 37 and $38 \mathrm{GW}$. In all of them, treatment with phototherapy for $24 \mathrm{~h}$ it was needed, and they were discharged without complications.

\section{Discussion}

LBWN continues to be a challenge for both the pediatrician and the neonatologist, even more, if it cannot be established during pregnancy if this weight loss is due to factors specific to the product or due to aggression from its environment. The present data support that knowing the maternal history can help predict possible early postnatal complications. In the first place, the LBWN of "sick" mothers was obtained by cesarean sections performed earlier (> 50\% at $37 \mathrm{GW}$ ). Likewise, compared with their counterparts of lower gestational ages (37 and $38 \mathrm{GW}$ ), they weighed less at birth (37 GW $p<0.02$ and 38 GW $p=0.16$ ), even with similar sizes, and exhibited an increased risk of HG. However, they reached a higher level of pulmonary maturation manifested by a lower proportion of RD. On the other hand, more mature neonates (39-41 GW), children of mothers with a prenatal history were smaller. This group, moreover, did not present any event of neonatal HG.

The presence of RD was high in both groups, especially in those of 37 and $38 \mathrm{GW}$. Finally, $\mathrm{HBr}$ was not associated with the antecedent and was a rare complication in the LBWNs that were studied.

As has already been reported in the literature, maternal age has been widely related to the risk of low neonatal weight ${ }^{1,4}$. Therefore, it was not surprising that 
Table 2. Characteristics of low-birth-weight neonates for gestational age according to antecedents of prenatal disease.

\begin{tabular}{|c|c|c|c|c|}
\hline & $\begin{array}{l}\text { With antecedent } \\
\qquad n=58(\%)\end{array}$ & $\begin{array}{c}\text { Without antecedent } \\
n=291(\%)\end{array}$ & $\begin{array}{c}\text { Total } \\
\mathrm{n}=\mathbf{3 4 9}(\%)\end{array}$ & p value \\
\hline $\begin{array}{l}\text { Sex } \\
\text { Female } \\
\text { Male }\end{array}$ & $\begin{array}{l}63.8(37) \\
36.2(21)\end{array}$ & $\begin{array}{l}64.3(187) \\
35.7(104)\end{array}$ & $\begin{array}{l}64.2(224) \\
35.8(125)\end{array}$ & $1.00^{*}$ \\
\hline $\begin{array}{r}\mathrm{GW} \\
37 \\
38 \\
39 \\
40 \\
41\end{array}$ & $\begin{array}{c}55.2(32) \\
25.9(15) \\
12.1(7) \\
6.9(4) \\
0\end{array}$ & $\begin{array}{c}35.1(102) \\
39.2(114) \\
18.9(55) \\
5.2(15) \\
1.7(5)\end{array}$ & $\begin{array}{c}38.4(134) \\
37.0(129) \\
17.8(62) \\
5.4(19) \\
1.4(5)\end{array}$ & $0.037^{* *}$ \\
\hline $\begin{array}{l}\text { Delivery method } \\
\text { Cesarean section } \\
\text { Natural birth }\end{array}$ & $\begin{array}{l}82.8(48) \\
17.2(10)\end{array}$ & $\begin{array}{l}79.7(232) \\
20.3(59)\end{array}$ & $\begin{array}{l}80.2(280) \\
19.8(69)\end{array}$ & $0.59^{*}$ \\
\hline $\begin{array}{l}\text { Birth weight (g) } \\
37 \mathrm{GW} \\
38 \mathrm{GW} \\
39 \mathrm{GW} \\
40 \mathrm{GW}\end{array}$ & $\begin{array}{c}2284 \pm 222 \\
2434 \pm 132 \\
2496 \pm 124 \\
2607 \pm 75\end{array}$ & $\begin{array}{c}2380 \pm 148 \\
2488 \pm 174 \\
2528 \pm 113 \\
2611 \pm 71\end{array}$ & & $\begin{array}{c}0.028^{+} \\
0.169^{+} \\
0.54^{+} \\
0.092^{+}\end{array}$ \\
\hline $\begin{array}{l}\text { Size at birth }(\mathrm{cm}) \\
37 \mathrm{GW} \\
38 \mathrm{GW} \\
39 \mathrm{GW} \\
40 \mathrm{GW}\end{array}$ & $\begin{array}{l}46.1 \pm 1.5 \\
46.8 \pm 1.3 \\
46.8 \pm 1.4 \\
47.2 \pm 0.9\end{array}$ & $\begin{array}{l}46.5 \pm 1.4 \\
47.1 \pm 1.4 \\
47.9 \pm 1.2 \\
47.6 \pm 1.2\end{array}$ & & $\begin{array}{l}0.225^{+} \\
0.464^{+} \\
0.039^{+} \\
0.542^{+}\end{array}$ \\
\hline $\begin{array}{l}\text { APGAR (at } 5 \mathrm{~min} \text { ) } \\
7 \\
8 \\
9 \\
10\end{array}$ & $\begin{array}{c}0 \\
3.4(2) \\
91.4(53) \\
5.2(3)\end{array}$ & $\begin{array}{c}0.3(1) \\
4.5(13) \\
91.1(265) \\
5.2(3)\end{array}$ & $\begin{array}{c}0.3(1) \\
4.3(15) \\
91.1(318) \\
4.3(15)\end{array}$ & $0.54^{* *}$ \\
\hline
\end{tabular}

*Two-tailed Fisher's exact test., GW: Weeks of gestation.

${ }^{* *} \chi^{2}$ test linear by linear.

+ Mean \pm DS, student's $t$-test.

Table 3. Postnatal complications of low birth weight neonates for gestational age according to antecedents of prenatal disease.

\begin{tabular}{|c|c|c|c|}
\hline & With maternal antecedent $(\%)$ & Without maternal antecedent & Difference $(95 \%$ CI ) \\
\hline $\begin{array}{l}\text { Respiratory distress syndrome } \\
37 \mathrm{GW} \\
38 \mathrm{GW} \\
39 \mathrm{GW} \\
40 \mathrm{GW}\end{array}$ & $\begin{array}{c}18.8(6 / 32) \\
0(0 / 15) \\
28.6(2 / 7) \\
25.0(1 / 4)\end{array}$ & $\begin{array}{c}23.5(24 / 102) \\
10.5(12 / 114) \\
10.9(6 / 55) \\
20.0(3 / 15)\end{array}$ & $\begin{array}{c}-4.7(-20.6-11.05) \\
-10.5(-4.8--16.1) \\
17.8(-16.8-52.1) \\
5(-42-52)\end{array}$ \\
\hline $\begin{array}{l}\text { Hypoglycemia } \\
37 \mathrm{GW} \\
38 \mathrm{GW} \\
39 \mathrm{GW} \\
40 \mathrm{GW}\end{array}$ & $\begin{array}{c}31.3(10 / 32) \\
26.7(4 / 15) \\
0(0 / 7) \\
0(0 / 4)\end{array}$ & $\begin{array}{c}17.6(18 / 102) \\
14.0(11 / 16) \\
12.7(7 / 55) \\
0(0 / 15)\end{array}$ & $\begin{array}{c}13.6(-4.08-31.2) \\
12.6(-10.6-35.9) \\
-12.7(-3.9--21.5) \\
-\end{array}$ \\
\hline $\begin{array}{l}\text { Hyperbilirubinemia } \\
37 \mathrm{GW} \\
38 \mathrm{GW} \\
39 \mathrm{GW} \\
40 \mathrm{GW}\end{array}$ & $\begin{array}{l}0(0 / 32) \\
0(0 / 15) \\
0(0 / 7) \\
0(0 / 4)\end{array}$ & $\begin{array}{c}1.0(1 / 102) \\
1.8(2 / 114) \\
0(0 / 55) \\
0(0 / 15)\end{array}$ & $\begin{array}{c}-0.9(-2.8-0.9) \\
-1.7(-4.1-0.6) \\
- \\
-\end{array}$ \\
\hline
\end{tabular}

GW: gestation weeks; $95 \% \mathrm{Cl}=95 \%$ confidence interval. 
the median age of the mothers was 34.5 years, but it was surprising to find a slightly older age (1 year) in those with diseases during their pregnancy. Likewise, the age over 34 years has also been related to an increased risk to suffer gestational diseases. In particular, the hypertensive disease of pregnancy and $\mathrm{HT}^{9,15-17}$, both highly prevalent disease in this study.

Both the hypertensive disease of pregnancy and HT usually affect fetal growth by altering the placental flow and the necessary hormones for the product development, unlike diabetes mellitus, whose main effect is fetal macrosomia ${ }^{9,15,6,18}$. The lower gestational age found in the products of these mothers can be related to the need to interrupt pregnancy earlier due to the risk of morbidity or mortality of both the mother and the product ${ }^{16}$. However, observing a lower weight of their children compared with their counterparts of the same gestational age reaffirms the impact of these diseases on fetal growth.

Regarding the delivery method, as was observed in these patients, obtaining through cesarean section was highly frequent. In general, the decision is usually based on the high risk of neonatal hypoxia due to low fetal reserve expected in any fetus that has not reached a normal weight for gestational age, without considering the obstetric recommendation of this procedure in mothers over 35 years of age, especially primiparous (frequent condition in this study) $)^{4,5,9,16}$. No differences were found between the groups. The most significant was the meager rate of patients with Apgar $<7$ at 5 min after birth (only one patient): by not showing acute or chronic fetal distress, a state of hypoxia in the fetus that resulted in polycythemia with a high risk of presenting $\mathrm{HBr}$ did not develop ${ }^{1,5,14}$. On the other hand, it is known that a cesarean birth in term children is associated with type II neonatal RD syndrome ${ }^{1,8}$. This could be observed by a frequency of $20 \%$ and $25 \%$ of the children of mothers with and without antecedents, respectively. However, a more significant difference was observed in neonates with lower gestational age (37 and $38 \mathrm{GW}$ ). In them, RD was less present when there was a history of the maternal disease. Some studies have shown that the fetus, being subjected to constant stress in an environment of hypoxia and fetal distress, has a faster pulmonary maturation, a condition that protects them from developing a syndrome of $\mathrm{RD}$ at birth, but also increases the risk of meconium aspiration syndrome ${ }^{1,8}$.

Regarding the risk of neonatal $H G$, it is known that LBWNs have low concentrations of intrauterine insulin, and therefore, a decrease in the synthesis and deposition of hepatic glycogen; therefore, at birth, they require an early feeding, as fast as the severity of the IUGR $^{18}$. In this study, we observed a slightly higher frequency of $\mathrm{HG}$ in newborns from 37 to $38 \mathrm{GW}$, especially in those with a maternal history, although the difference was not statistically significant. In contrast, for $39 \mathrm{GW}$ neonates, this event was infrequent and only occurred in the group of neonates without a maternal disease. It is possible that neonates from 39 to $40 \mathrm{GW}$ have managed to supply their reserves during these two extra WG.

This study presented several strengths. First, the sample was broad enough to contrast the effect of the most common maternal history on the most usual complications in term neonates. Second, these patients were followed throughout their evolution, which allowed close monitoring, as well as timely interventions, to avoid significant complications. In contrast, several limitations must be considered in this work. It was not possible to establish a strict difference between small newborns for gestational age and newborns with a precise diagnosis of intrauterine restriction. This finding is important because it allows a better clarification of the risks of specific complications.

Despite these limitations, these data support the usefulness of evaluating maternal history in all low-weight products. As observed in the results, when these are present, it is possible to think of a product that besides being underweight could have a restriction on growth, and therefore, a higher risk of early $\mathrm{HG}$. In the absence of this background, the newborn could have a low growth due to a constitutional component, and obtaining it in a minimal period (37-38 GW) puts it at risk of $\mathrm{RD}$. In these children, the decision of continuing the pregnancy would be an option despite estimating a low weight. Finally, obstetric and neonatal management in all LBWN should be assessed as a whole, and preferably supported by prenatal imaging studies that allow a better decision.

Gathering maternal history related to gestational diseases, such as hypertensive disease of pregnancy, maternal HT, and among others, in pregnancy with LBW product seems to be useful in the inference of possible IUGR. However, in an isolated manner, it is not a reliable indicator on the risk of postnatal complications, so the prenatal clinical history, adequate prenatal control and close monitoring of the new borne together will help to estimate complications and preventive actions. 


\section{Ethical disclosures}

Protection of human and animal subjects. The authors declare that no experiments were performed on humans or animals for this study.

Confidentiality of data. The authors declare that they have followed the protocols of their work center on the publication of patient data.

Right to privacy and informed consent. The authors declare that no patient data appear in this article.

\section{Conflicts of interest}

The authors declare no conflicts of interest.

\section{References}

1. Arango F, Grajales J. Restricción en el crecimiento intrauterino. CCAP 2010;9:5-14.

2. Boguszewski M, Mericq V, Bergada I, Damiani D, Belgorosky A. Consenso Latinoamericano: niños pequeños para la edad gestacional. Rev Chil Pediatr. 2012;83:620-634.

3. Labarta J, de Arriba A. Consecuencias de nacer pequeño para la edad gestacional. Bol S Vasco-Nav Pediatr. 2013;45:32-33.

4. Pimiento L, Beltrán M. Restricción del crecimiento intrauterino: Una aproximación al diagnóstico, seguimiento y manejo. Rev Chil Obstet Ginecol. 2015;80:493-502.

5. Gormaz M. Pequeño para la edad gestacional en el periodo neonatal. Rev Esp Endocrinol Pediatr. 2012;3:90-92.

6. Gómez M, Danglot $\mathrm{C}$, Aceves M. Clasificación de los niños recién nacidos. Rev Mex Pediatr. 2012;79:32-39.
7. Parca M, Peloso T, Dos Anjos M. Frequency and risk factors for the birth of small-for-gestacional-age newborns in a public maternity hospital. Einstein. 2016;14:317-323.

8. Castro F, Labarrere Y, González G, Barrios Y. Factores de riesgo del síndrome de dificultad respiratoria de origen pulmonar en el recién nacido. Rev Cubana Enfermer. 2007;23:1-15.

9. Salazar L, Gómez T, Bequer L, Heredia D. El bajo peso como consecuencia de la hipertensión inducida por el embarazo. Factores de riesgo. Rev Hosp Mat Inf Ramón Serdá. 2014;33:14-20.

10. Jurado E. El crecimiento intrauterino. Correlación peso/longitud corporal al nacimiento en función de la edad de gestación. Gac Med Mex. 1971;102:227-255.

11. Guía de Práctica Clínica. Diagnóstico y tratamiento de la taquipnea transitoria del recién nacido. Evidencias y recomendaciones. Catálogo maestro de guías de práctica clínica. IMSS 044-08. Available at: http:// www.cenetec.salud.gob.mx/descargas/gpc/CatalogoMaestro/044_GPC_ TaquipneaTransRN/IMSS_044_08_EyR.pdf

12. Guía de Práctica Clínica. Diagnóstico y tratamiento de la hipoglucemia neonatal transitoria. Evidencias y recomendaciones. Catálogo maestro de guías de práctica clínica. IMSS 442-11. Available at: http://www.cenetec.salud.gob.mx/descargas/gpc/CatalogoMaestro/446_GPC_Hipoglucemia_neonatal/GER_Hipoglucemia_neonatal.pdf

13. Guía de Práctica Clínica. Detección oportuna, diagnóstico y tratamiento de la hiperbilirrubinemia en niños mayores de 35 semanas de gestación hasta las 2 semanas de vida extrauterina. Evidencias y recomendaciones. IMSS 262-10. Available at: http://www.cenetec.salud.gob.mx/descargas/gpc/CatalogoMaestro/262_IMSS_10_Hiperbilirrubinemia/EyR IMSS_262_10.pdf

14. Mazzi E. Hiperbilirrubinemia neonatal, actualización. Rev Soc Bol Pediatr. 2005; $44: 26-35$

15. Ulanowick M, Parra K, Rosas G, Hipertensión Gestacional. Consideraciones generales, efectos sobre la madre y el producto de la concepción. Rev Posgr VI Cátedra Med. 2005;152:19-22.

16. Gómez M, Danglot C. El neonato de madre con preeclampsia-eclampsia. Rev Mex Pediatr. 2006;73:82-88.

17. Serrano M. Alteraciones de tiroides y embarazo: resultados perinatales. Rev Esp Med Quir. 2013;18:200-205.

18. Arizmendi J, Carmona V, Colmenares A, Gómez D, Palomo T. Diabetes gestacional y complicaciones neonatales. Rev Fac Med. 2012; 20:50-60. 